\title{
IMPLEMENTATION OF TEXT-TO-SPEECH AUDIO SYSTEM IN ISIXHOSA FOR DWESA COMMUNITY IN EASTERN CAPE PROVINCE OF SOUTH AFRICA ${ }^{1}$
}

\begin{abstract}
Dr. ZW Saul, the Head of the Department of African Languages at the University of Fort Hare, was considering the future of a text-to-speech system that converted English text into isiXhosa audio. The system had experienced a successful pilot, but much work remained to be done in taking the project to full implementation and sustainability.
\end{abstract}

The relevance of the system to the community in the Dwesa area and other communities where isiXhosa was the first language stemmed from the language policies of the country. The national government of the Republic of South Africa had put in place policies for promoting the use of indigenous languages in South Africa. These were important policies because in the previous dispensation indigenous languages did not receive adequate support and were not accorded official status. The democratic government wanted to address this imbalance in the lives of the people of the country. There were various initiatives by the national government to promote indigenous languages on television, on radio and in other aspects of life in the Republic of South Africa. For instance the national broadcaster, the South African Broadcasting Corporation, had targeted $90 \%$ locally produced content on radio and television. It was expected that a large portion of that content would be in indigenous languages.

Dr. Saul had three issues to address in his decision. The first issue was that TelkomSA, the major funder of the Centre of Excellence (a joint project of the University of Fort Hare and Rhodes University) had yet to determine whether to fund the project into full implementation. The second issue revolved around the commercialization of the project so that it could become a project that generated jobs and income for members of the community. The third issue was related to maintenance of the computer infrastructure and the computer labs. The infrastructure was maintained by students from the TelkomSA Centre of Excellence. For full implementation of the project, it would not have been possible to make use of these student volunteers to maintain the system.

Dr. Saul had four options for funding the project. Either the community could pay for these services themselves or the project could be handed over to a business operator or the government would have to take over the project. Or, possibly, another funding plan could be developed.

\footnotetext{
${ }^{1}$ Copyright (C) 2018, Siphe Mhlana and Vincent Z Mzazi. This case was prepared for the purpose of class discussion. Names and some information have been disguised. This case is published under a Creative Commons BY-NC license and originally appeared as a chapter in Transforming Society Using ICT: Contemporary Discussion Cases from Africa. Permission is granted to copy and distribute this case for non-commercial purposes, in both printed and electronic formats.
} 


\section{Background}

The idea to implement the app was derived from various motivations including the history of the Republic of South Africa, the national constitution as well as the language provisions in the relevant acts of parliament. For much of its recent history, English and Afrikaans had been the dominant languages of the country. In the democratic dispensation that came about in 1994 and ended apartheid, a decision was made to adopt the value of promotion and use of indigenous languages in South Africa. After 1994, eleven official languages could be used in parliament, in the educational sectors and other realms of life. There were approximately eight million isiXhosa indigenous language speakers in the Republic of South Africa, isiZulu had about eleven million indigenous speakers, Setswana had about four million, Southern Sotho and Northern Sotho also had about four million each. The promotion and use of indigenous languages was covered by several acts in the republic including the Pan South African Language Board Amendment Act of 1999 (see Exhibit 1), and Section 6, 29, 30 and 31 of the Constitution of the Republic of South Africa of 1996 (National Government Republic of South Africa 1996).

Geographically, the project was undertaken in the Dwesa community in the Eastern Cape Province of the Republic of South Africa. South Africa had nine provinces (see Exhibit 2), each of which had its own local government. The Eastern Cape was one of the provinces of South Africa (National Government Republic of South Africa 2017) and was heavily populated by the Xhosa people (see. Exhibits 3, 4, 5 and 6). The Dwesa community was located in the Wild Coast area of the Eastern Cape, and it fell under the Mbhashe Local Municipality, which was deep in the rural areas of the Wild Coast (see Exhibit 5). The Wild Coast was the least developed area in the Eastern Cape, despite having good rainfall and fertile grounds for agriculture. The Dwesa community (see Exhibit 6) was located on a land area of approximately 15,254 hectares, with approximately 15,000 people occupying the area divided into roughly 2,000 households (National Government Republic of South Africa 2017). According to the records of Statistics South Africa, the Mbashe Local Municipality had a population of about 254,000 in 2016.

In the Dwesa community there were e-services applications that had been deployed for the community members as part of the Siyakhula Living Labs project-Siyakhula being the isiXhosa word meaning "we are growing together". The Siyakhula Living Labs project was managed and funded by the TelkomSA Centre of Excellence. Some of the applications in the Siyakhula Living Labs included an e-commerce platform, e-judiciary service, e-health and e-government portal (Gumbo, Thinyane, Thinyane, et al. 2012; Dhir et al. 2012). These services were accessed through computer facilities located at the four secondary schools in the community, namely: Mpume Junior Secondary School, Ngwane Junior Secondary School, Mtokwane Junior Secondary School and Nondobo Junior Secondary School.

The telecommunication infrastructure of the four schools consisted of satellite based connectivity. The main components of the telecommunication network w the following: Mpume Junior Secondary School had a Very Small Aperture Terminal (VSAT) connection and Access Concentrator; Ngwane Junior Secondary had an Alvirion Breemax Micro base station, which transmitted signals to the computer laboratories at the schools. The computer laboratories at each of the schools were each equipped with desktop clients, a FreeBSD router and a server running Linux terminal. Details about the telecommunications infrastructure at the Siyakhula Living Labs were described by Gumbo et al. (2012).

In each of the four schools, a teacher was given the task of managing the computer lab and providing access to the lab when the members of the community wanted to use the computers. Such teachers were trained on how to maintain an internet connection and other minor network administration duties. They also worked with researchers from the University of Fort Hare and Rhodes University. In case of a serious technical failure, the teacher would report it to the students from either of the universities. The students 
would then go down to Dwesa and attend to the problem. The four computer centres in the Dwesa community were part of the Siyakhula Living Labs.

Although the first language of the population in the Dwesa community was isiXhosa, the e-service interfaces were written in English. This was a problem because most members of the Dwesa community did not understand English. Moreover, the lack of isiXhosa on the interfaces on these systems was counter to the values of the new dispensation of promoting the use of indigenous languages in South Africa (Prah 2006). Therefore, the decision was made to develop an app for translating English text into isiXhosa audio under the auspices of the Siyakhula Living Labs.

\section{The Department of African Languages of the University of Fort Hare}

The Department of African Languages at the University of Fort Hare fell under the Faculty of Social Sciences and Humanities. That faculty was established in 2005 as a partial outcome of the university's strategic planning process to facilitate the merger of the East London Campus with the Alice Campus of the university.

The establishment of the Faculty of Social Sciences and Humanities gave academic staff at the university an opportunity to take a fresh look at the nature of their programmes and to explore the possibilities of making programmes more exciting and marketable. The department shared a vision of empowering and equipping their students with language competencies and skills that would make them dynamic language practitioners - who could be employed or even set up their own businesses.

This department also strived to play an important role in maintaining the originality of the indigenous languages in South Africa. They were committed to offering high quality courses and programmes that would equip the students with cutting edge knowledge and make them prominent leaders in their respective areas of specialization. The department was very influential in the communities of the Eastern Cape and the National Department of Higher Education.

The role that was played by the Department of African Languages was that of a project champion. Dr. Saul, the head of the department, was championing the project within the university as well as within government circles and in the community at large.

\section{Industry and Government}

The main industry stakeholder in the project was TelkomSA, through its TelkomSA Centre of Excellence in Distributed Multimedia, established in March 1997. The Centre also had other partners in the private sector and in government.

The main government stakeholder in the project was the national Department of Science and Technology (DST). The DST had partnered with the Department of International Relations and Cooperation to establish a country bilateral cooperation with the Government of Finland. One of the programmes formed under this partnership was the South Africa-Finland Knowledge Partnership on ICT (SAFIPA). The overall objective of the programme was to support the creation of an environment that facilitated the development and deployment of ICT implementations for the benefit of the citizens of the Republic of South African. One of the goals of the programme was to address the creation and delivery of ICT services that were suitable for local conditions, especially in areas that were inhabited by populations that were not socio-economically strong. The Siyakhula Living Labs benefited from these bilateral agreements. For instance, there were funds that were made available to the Siyakhula Living Labs project 
and a student exchange programme involving the two countries. This exchange programme involved several students from Finland who came to assist with the implementation of the Siyakhula Living Labs project.

Other than providing equipment and connectivity for the project, TelkomSA also assisted in the training of postgraduate students. In addition, TelkomSA provided bursaries for students to study towards computer science and engineering qualifications. As a precondition for the sponsorship, the students could only pursue areas related to the projects of the Centre of Excellence in Distributed Multimedia at Rhodes University. The developer of the text-to-speech system, Mr Siphe Mhlana, was one of the postgraduate students who received sponsorship from TelkomSA (Mhlana 2011). Upon completion of their studies, the students were given an opportunity to work for TelkomSA for the number of years that they were sponsored.

With the scaling up of implementation, TelkomSA seemed likely to withdraw its funding. Scaling up of the project would involve substantially more resources than had been used during the piloting phase. So the owners of the project would have to source funding and resources elsewhere in order to meet the operational needs of the project.

\section{Community Leadership}

The rural communities of the Eastern Cape were being ruled by headmen, sub-headmen and elected councillors. Most issues affecting the communities were referred to this leadership, and very often they would arrange community meetings in order to make decisions. Not much could be done in these communities without first getting the go-ahead of the headmen. There was a hierarchy among the headmen, with some headmen having authority over several surrounding sub-headmen. These headmen and sub-headmen met periodically. Some of the issues addressed by the headmen included resolving disputes in the communities and the allocation of land for people to build homes. The ICT projects that were introduced in the community also needed approval from the headmen.

These traditional leaders (headman and sub-headman) were able to mobilise the people in these communities when there was a new intervention that would benefit community members. Therefore, the headmen also played a role in the implementation and acceptance of ICTs projects by the community. They could also persuade community members to accept or reject ICT projects, as well as assist implementers in various ways.

Church leaders also played a crucial role in the rural communities. The churches allowed community members to conduct their meetings in church buildings. They also gave spiritual guidance to the leaders and members of the community at large.

School headmasters (principals) and teachers were also part of the community leadership and commanded respect in the community. There were also ward councillors and ward committees whose role was administrative. The ward councillors were elected by the population and represented their respective political parties. The role of the councillors was to ensure proper administration of their wards and the provision of adequate services in their wards.

The complex system of community leadership would likely play a major role in the scaling up of the isiXhosa text-to-speech system. Communities would need to be mobilized; gaining the support of community leadership would be critical for scaling up the system implementation. If the community could be mobilized, they would use this service even if a requisite fee was charged. Alternatively, or in conjunction with fees, the community could collectively lobby the government to fund the project out of 
its budget. The unity and resolve of the community would be very important in convincing the government to take over the project.

\section{Factors affecting sustainability of community-based projects}

Implementers of community-based projects such as the text-to-speech system in the Dwesa community needed to plan for sustainability of their projects. In the initial phase of implementation of communitybased projects, the focus was usually on validation of the intervention and on determining programme efficacy. In the case of the text-to-speech system, the first phase had been successfully completed. The technology used in the system had been validated and the response of the users to the system was also tested. The implementers of the project needed then to address the matter of sustainability of their project.

There are various definitions of sustainability; however the one used in this discussion case is the following:

A development project is sustainable when it is able to deliver an appropriate level of benefits for an extended period of time after major financial, managerial and technical assistance from an external donor is terminated.

This definition was a good fit with the text-to-speech system in isiXhosa-particularly given the strong possibility that the TelkomSA Centre of Excellence would no longer fund the project into full implementation.

There were several factors that needed to be considered when planning for sustainability. Ensuring financial viability of the project was very important. For example, were the members of the community going to pay for this service? Or would the programme be integrated into the programmes of the government after donor funding came to an end? In order to ensure economic viability, the resources needed for the project could not exceed those available in the community. In the case of integration with other programmes of the government, the project could not require resources that were beyond the means of the relevant government department.

For it to succeed, a community-based project always needed a project champion. The champion of the project had to be someone with a clout and who had access to the ears of people in authority. The champion ought to have been able to lobby for their project in an environment where competition for resources was very stiff. Another factor contributing to the success of the project was staff continuity. High turn-over of staff in a community-based project was not an option; chances of the success of the project would be far greater under an environment of stable personnel than remaining with the programme as it developed and grew over many years.

An example of sustainable success for a community-based project was that of a community health workers project in the inner city areas of Baltimore in the USA (Shediac-Rizkallah \& Bone 1998). This project achieved sustainability by linking up with established hospitals and health providers in the city that disbursed funds to the project for their health promotion activities and other duties that they performed in the community on behalf of the service providers. Other than having a powerful champion who assisted the project over many years, the project had visible buy-in from the communities that were served by it. 
The project leadership team of the text-to-speech system in isiXhosa needed to learn from project team members of other similar projects.

\section{The Decision}

Dr. Saul needed to decide how to move forward with scaling up the implementation of the project and how to achieve sustainability. There were three issues that he needed to address going forward. The first was determining whether TelkomSA would continue to fund the project as it transitioned from a pilot to full implementation phase. The second involved the commercialization of the project; could it generate jobs and livelihood for members of the community? The final issue related to maintenance of the computer infrastructure and the computer labs. Currently, the infrastructure was maintained by students from the TelkomSA Centre of Excellence at the two universities. However, this was bound to change.

\section{The new role for the Department of African Languages}

As the champion of the project, Dr. Saul, had his own department as a resource. He concluded that the challenge of mapping the future of the project could also be an opportunity for his department. One of the things that Dr. Saul felt he involve students from his department in the project. In doing so, he would be fulfilling the department's role as one of the custodians of the indigenous languages in South Africa. The objective of assisting the students in his department was to make them leaders in their communities. It therefore made sense for the Department of African Languages to play a big role in scaling up implementation of the text-to-speech in isiXhosa system. Of course, such scaling up of the system depended on the continued operation of the Siyakhula Living Labs projects.

\section{Achieving project sustainability}

The likelihood was that upon the project's transition to full implementation, TelkomSA would withdraw its funding. The owners of the project therefore needed to look elsewhere for funding and to meet the ongoing operational needs of the project. There seemed to be four plausible avenues for continued funding:

1. The community could pay for these services themselves;

2. The project could be handed over to a business operator;

3. The government could take over the project;

4. Work could begin on identifying another funding source.

Getting the community to pay for implementation of the project would not be easy to achieve because of many competing economic challenges. The members of these communities had many pressing priorities in their lives such as buying groceries, taking children to school, and many other things. If the community were to contribute to fund the implementation of the project, the management of this fund would therefore become a critical requirement. There has previously been many cases of mismanagement of funds by people entrusted with public funds. The problem of management of funds might well prove to be a factor that could make members of the community reluctant to contribute to such a fund even if they had the capacity to do so.

The second option for funding of the project would be to hand over the project to a business operator. The business operator would offer this service in exchange for a payment by members of the community. There were several business models for online businesses, including advertising supported revenue models, subscription models and pay per access. How the business operator would collect payment for the 
services was a challenge that they would need to address. Fortunately, cellphone operators and banks offered many online payment solutions. Mobile phone payment methods seemed to offer the greatest promise because cellphones were quite widespread; many people owned cellphones even in remote rural areas.

Another decision related to handing the project over to a business operator would be whether to form a local business to take over the operation of the project or to give it to an operator outside the community. The benefit of forming a local business was that the members of the community, especially the youth, would be the business operators. The community would therefore experience direct economic benefits from the project. One challenge would be finding the skills required for operating the project within the community. Another challenge would be having sufficient funds to sustain the project within the community. Where the business operator was from outside the community, the community will not necessarily benefit from the project since the business operator's main motive would be profits, and not necessarily about developing the community.

The third funding option was the national government. As noted previously, the national government promoted the use of indigenous languages as one of its values. In this regard, the national government had a budget in several of its departments and agencies to use for the promotion of indigenous languages. For example, the Department of Arts and Culture had a number of initiatives in this area. Another possibility was the National House of Traditional Leaders (NHTL), a statutory body of the national government charged with advising the South African president and the national government on matters related to custom and traditional leadership. The additional responsibilities of the NHTL included acting as custodians of indigenous languages. In order to find the best source, there was a clear need to identify all potential suitable funding avenues available in government for the project.

The fourth option was to conduct further research on alternative funding sources. One such alternative was to obtain funding from corporate social investment programs of the big businesses in the country. Many organizations had corporate social investment programs. For example, community library projects and literacy projects had received such funding. Dr. Saul perceived that a text-to-speech conversion system was unique and might therefore be a project that would interest some corporate social investment program of one of the big funders. These programs tended to be interested in funding initiatives that were aligned to national values and promoted equity and redress in the country.

The challenge of relying on funding from corporate social investment programs would be that of sustainability. It was expected that such type of funding would simply delay the quest for sustainability since such investments were usually made for a fixed period of time or as a once-off disbursement. Funding from these sources could, however, provide a lifeline for the project while its owners refined their strategy for implementation of the project and developed a durable sustainability plan.

\section{References}

Dhir, A., Moukadem, I., Jere, N., and Kaur, P. (2012). Ethnographic examination for studying information sharing practices in rural South Africa, In: Proceedings of Advances in Computer Human Interactions Conference 2012.

Gumbo, S., Thinyane, H., Thinyane, M., Terzoli, A., \& Hansen S. (2012). Living labs methodology as an approach to innovation in ICT4D: the Siyakhula Living Labs experience. In: Proceedings of IST Africa Conference 2012. 
Mhlana S. (2011). Development of isiXhosa text-to-speech modules to support e-services in marginalized rural areas. [Master's degree dissertation]. University of Fort Hare. Republic of South Africa.

National Government Republic of South Africa. (1996). Constitution of the Republic of South Africa. [National constitution]. Pretoria (South Africa). Retrieved in July 2017, from https://www.gov.za/sites/www.gov.za/files/Act108of1996s.pdf .

National Government Republic of South Africa. (2017). Municipalities of South Africa. Retrieved in July 2017, from https://www.localgovernment.co.za/.

Prah, K.K. (2006). Challenges to the promotion of indigenous languages in South Africa, [Technical report - The Centre for Advanced Studies of African Society]. Retrieved in May 2018, from http://www.casas.co.za/FileAssets/NewsCast/misc/file/204_CV_Challenges\%20to\%20the\%20P romotion\%20of\%20Indidegous\%20Languages\%20in\%20Sou .pdf.

Shediac-Rizkallah, M.C., \& Bone, L.R. (1998). Planning for the sustainability of community-based health programs: conceptual frameworks and future research directions for research, practice and policy. Health Education Research, 13(1) pp. 87-108. 


\section{Acknowledgements}

This discussion case is based on research undertaken by Mr. Siphe Mhlana, one of the co-authors of the discussion case. The research was undertaken in fulfillment of Mr Mhlana's Master's degree. The research was carried out at the Siyakhula Living Labs in the Dwesa area. Dwesa is located in Mbashe local municipality in the Eastern Cape Province of the Republic of South Africa.

\section{Biography}
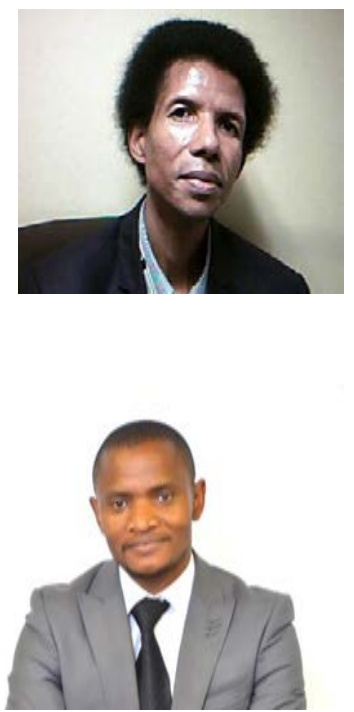

Vincent Mzazi (PhD) is a Senior Lecturer at the School of Computing at the University of South Africa. He holds a Master's degree in Computer Science from the University of Pretoria as well as a $\mathrm{PhD}$ in Community Health Medicine from Sefako Makgatho Medical School. His areas of research are health informatics, e-learning and community informatics. Vincent is presently the vice-chair of the ICT4D Flagship at the College of Science Engineering and Technology of the University of South Africa.

Siphe Mhlana (MSc) is a Lecturer at the School of Computing in the University of South Africa. He holds a Master's degree in Computer Science from the University of Fort Hare. He is currently studying towards his $\mathrm{PhD}$ in Computer Science at the University of South Africa. His research interests are: indigenous language systems, language conversion (text-to-speech), ICT in education and gender issues. He is presently a member of ICT4D Flagship of the University of South Africa. 


\section{Exhibit 1 - Excerpt from Pan South African Language Board Amendment Act of 1999}

\section{Amendment of section 8 of Act 59 of 1995}

6. Section 8 of the principal Act is hereby amended -

(a) in subsection(1)

(i) by the substitution for paragraph (f) of the following paragraph:

“(f) shall actively promote an awareness of the principle of multilingualism as a national resource by developing, administering and monitoring access, information and implementation programmes;”

(ii) by the substitution for paragraph (g) of the following paragraph:

" (g) shall actively promote the development of the previously marginalized languages by -

(i) developing, administering and monitoring access, information and implementation programmes; and

(ii) undertaking such duties for report on or relating to language development as it considers advisable in the exercise of its powers and the performance of its functions;”

(iii) in paragraph (j) -

(aa) by the substitution for the portion preceding subparagraph (i) of the following: "may, having regard to the constitutional provisions and principles dealing directly or indirectly with language matters in general and to section 3(9) of the Constitution in particular -

(bb) by the substitution for subparagraph (i) of the following paragraph:

"(iii) assist with and monitor the formulation of programmes and policies aimed at fostering the equal use of and respect for the official languages, while taking steps to ensure that communities using the languages referred to in section 3(10)(c) of the Constitution have the opportunity to use their languages in appropriate circumstances; ” 


\section{Exhibit 2 - Map showing provinces of the Republic of South Africa}

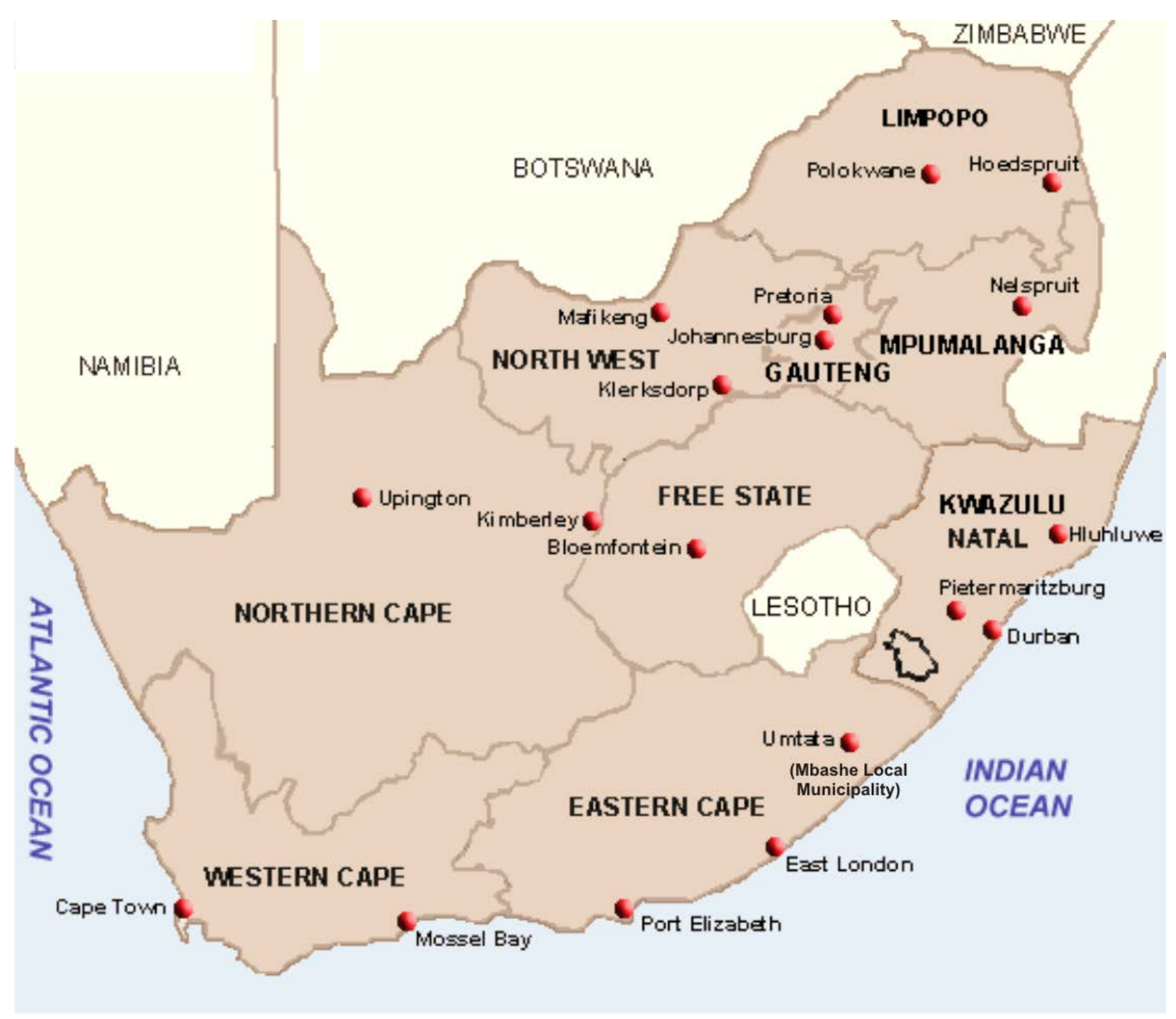


Exhibit 3 - A Xhosa gentleman and his bride

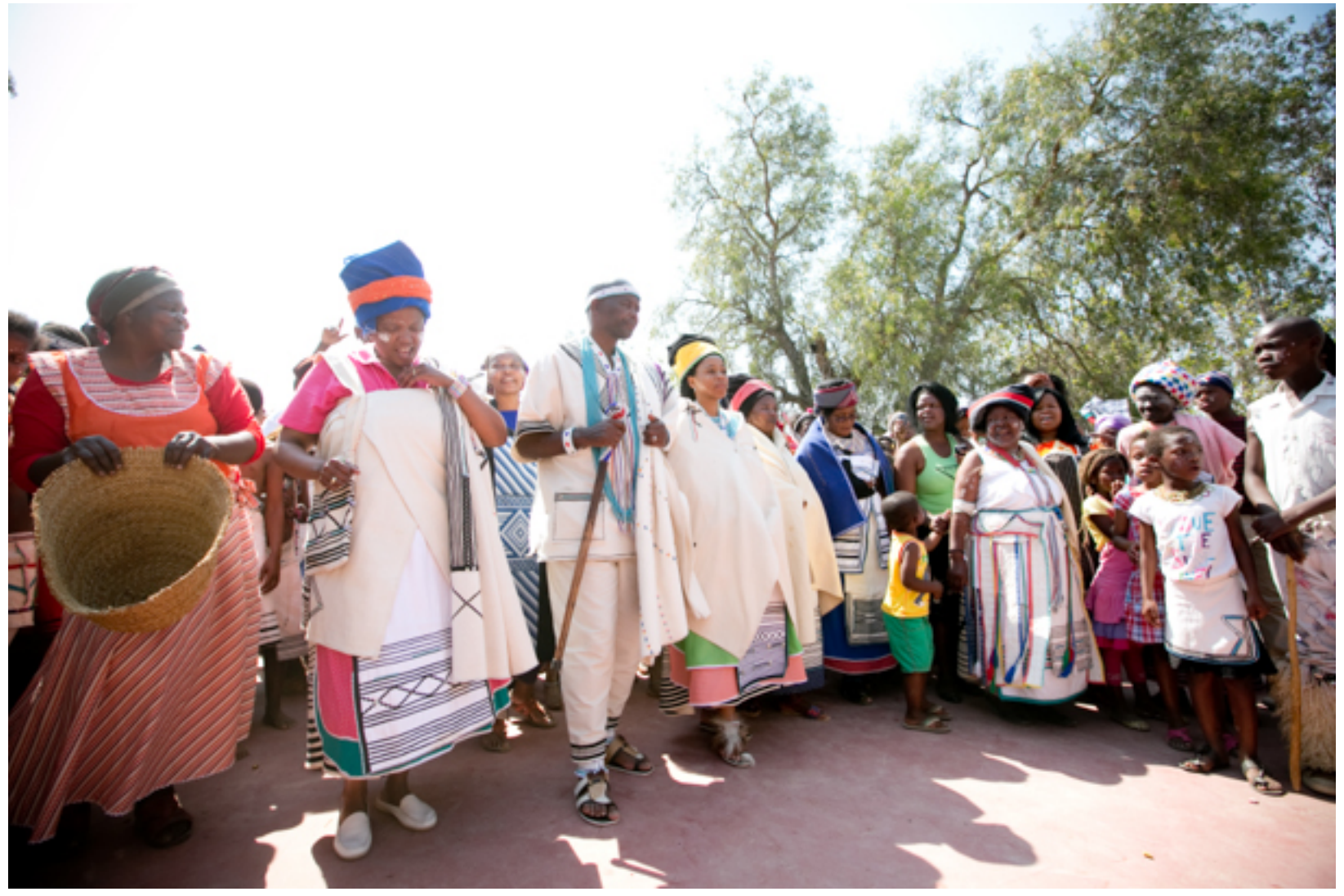




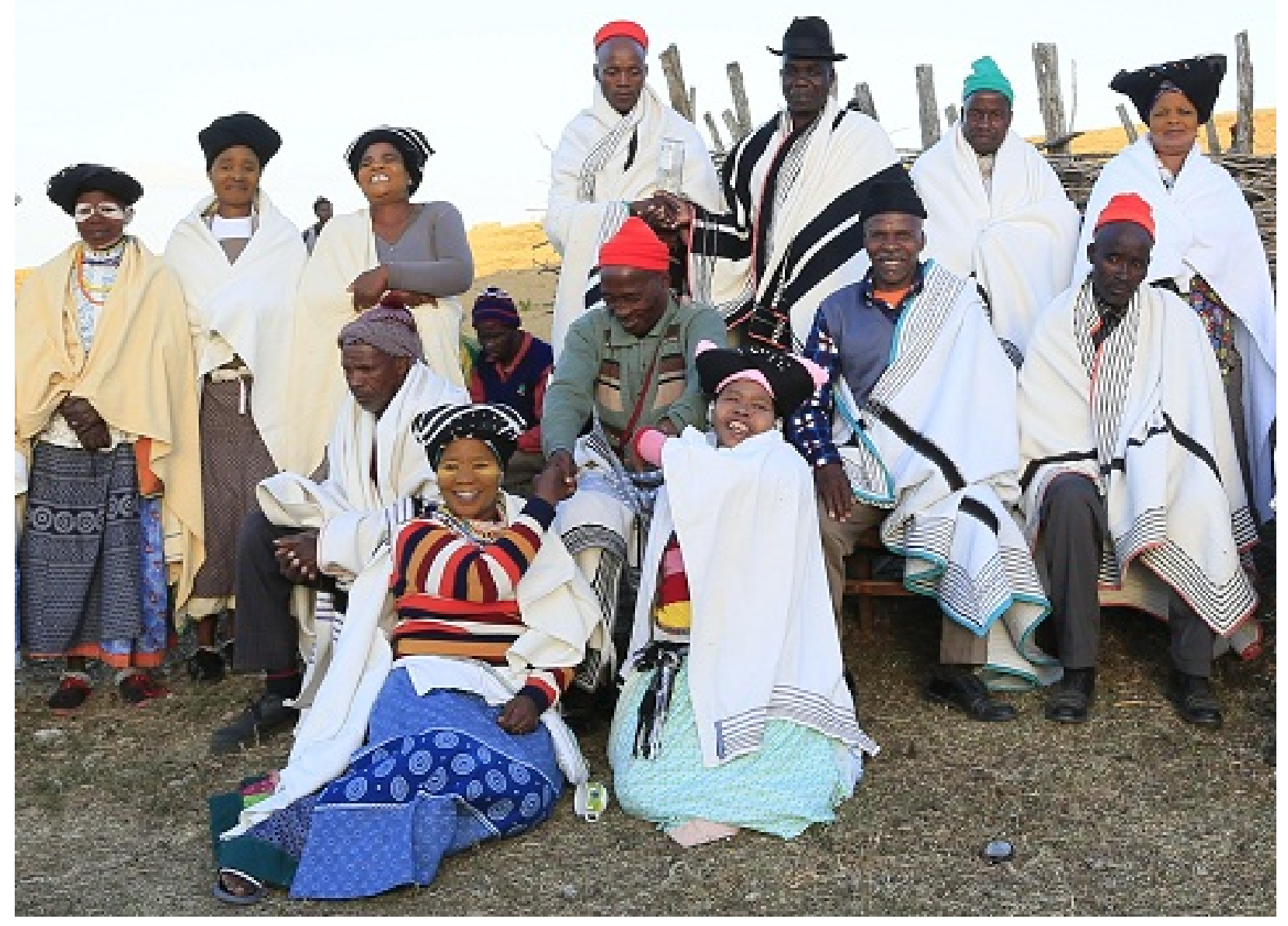




\section{Exhibit 5: A photo of a holiday resort on the Wild Coast}

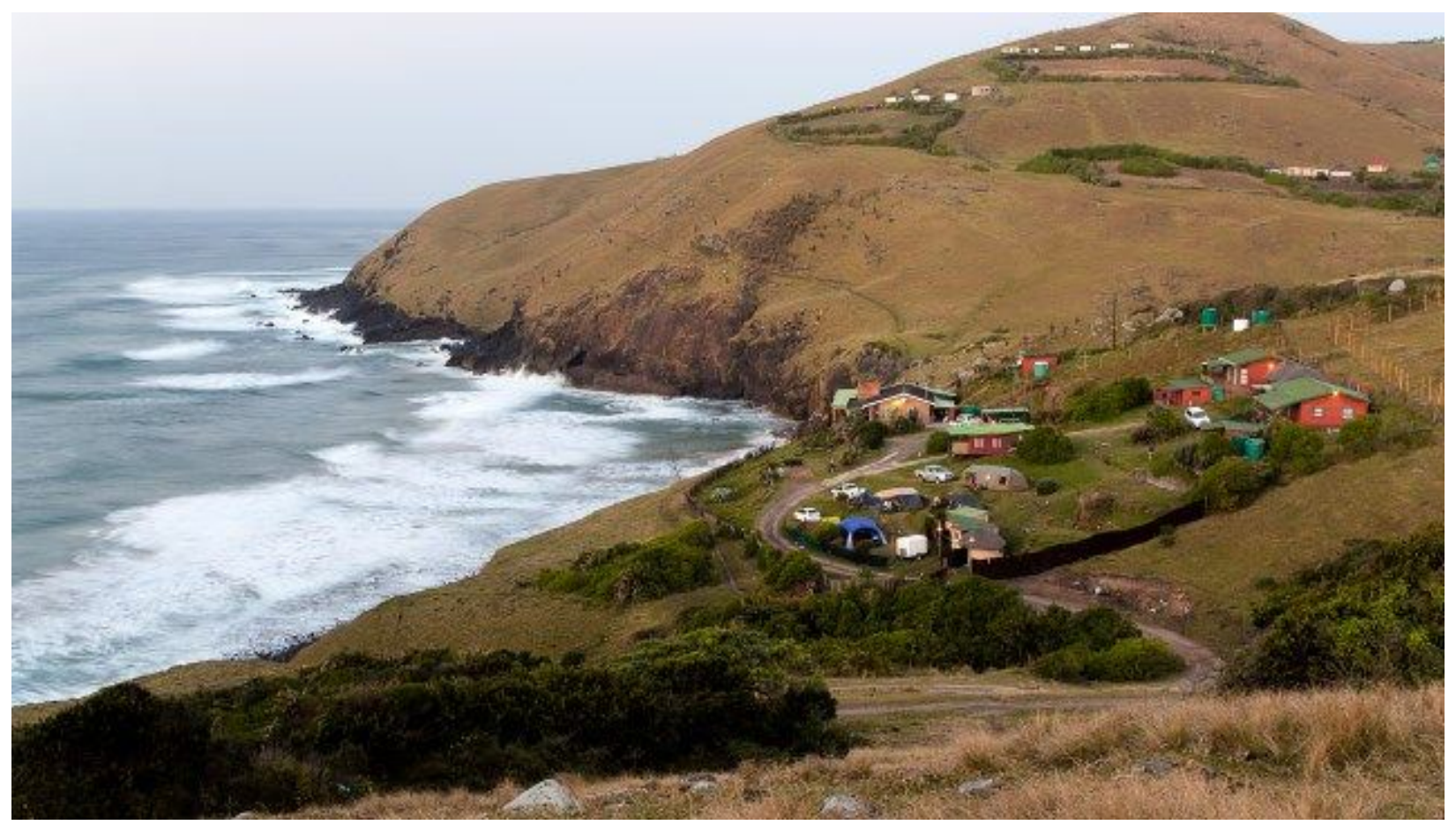


Exhibit 6: Sample photo of a Xhosa settlement and Xhosa lands

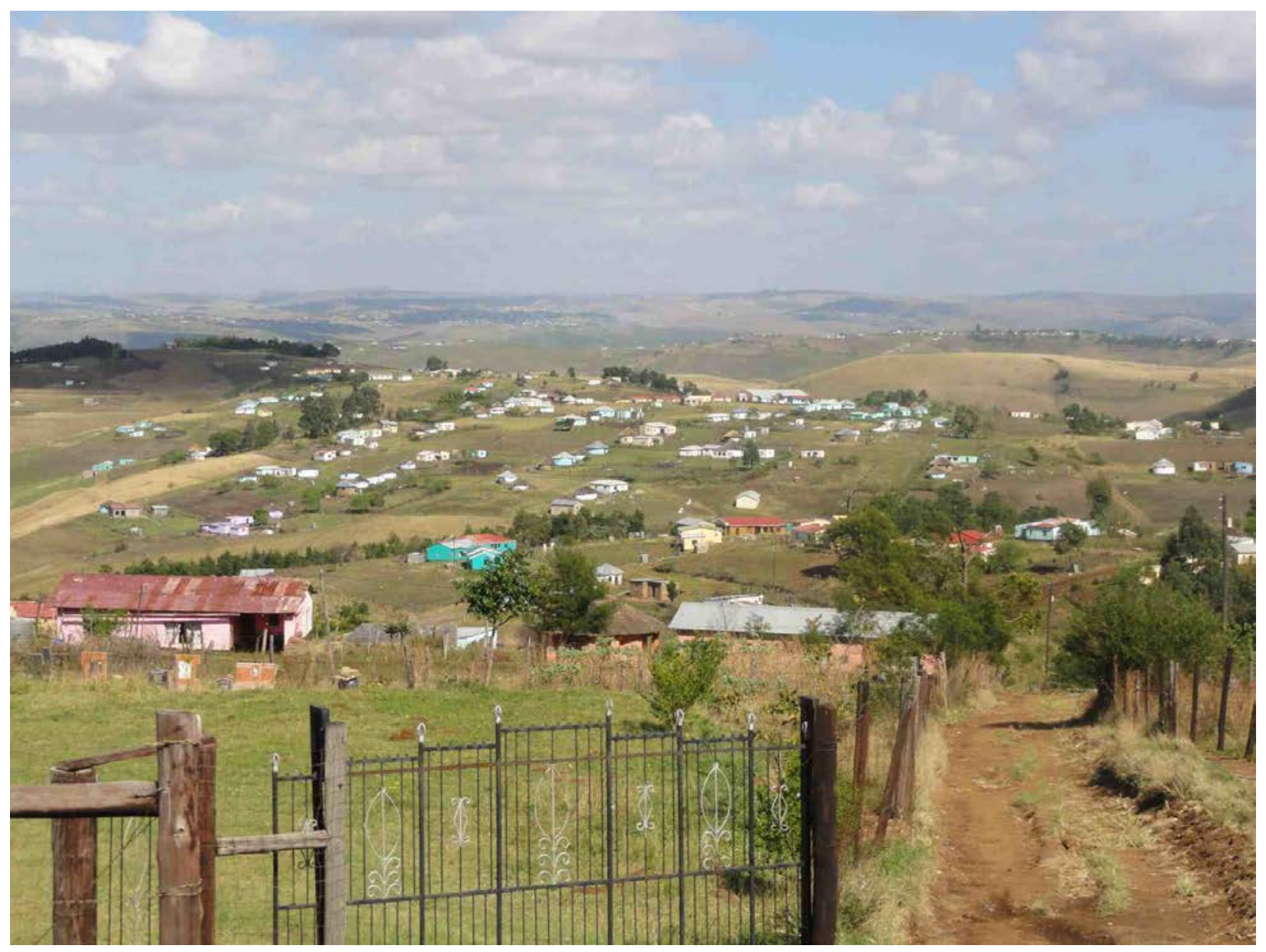

